PRACE GEOGRAFICZNE

zeszyt 158, 2019, 27-44

doi: 10.4467/20833113PG.19.014.10918

Instytut Geografii i Gospodarki Przestrzennej UJ

Komisja Geograficzna, Polska Akademia Umiejętności

Wydawnictwo Uniwersytetu Jagiellońskiego

\title{
WYSTĘPOWANIE MGEY NA WYBRANYCH LOTNISKACH W POŁUDNIOWEJ POLSCE I JEGO UWARUNKOWANIA GYRKULACYJNE
}

\author{
Magdalena Skræyńska
}

\section{Occurrence of fog in selected airports located in southern Poland and its circulation factors}

\begin{abstract}
This article discusses the annual course and the many-year occurrence of days with fog at three selected airports and their relationship with atmospheric circulation. Fog is a relatively frequent phenomenon - it is recorded around 60 days a year. Occurrence of fog is the most threatened airport Krakow-Balice, and least Katowice-Muchowiec. Fog usually occurred in autumn, and the least in summer. The probability of fog occurring is greatest in autumn and winter. Among the advection types, the types from the southern sector play a large role in shaping the mists. The highest probability of occurrence of a day with fog occurs in the types of non-convective circulation. In these circulation conditions, radiation mists are formed, which are the dominant type of mists in southern Poland. In spring and summer, the probability of fog is the lowest. The analysis confirms that the duration of the fog represents the leading role of the landform of the airport. Short-time fogs mostly occur mainly in Balice, whereas fogs of varying duration have similar frequencies at all airports considered. The most frequent occurrences of the 24-hour fog occur also in Balice, which means that the airport is characterized by the greatest threat to the fluency of air traffic. It is responsible for the location of the aerodrome within the concave form of the land, which is characterized by a tendency to create cold air stagnation and ground temperature inversion. Through a detailed analysis of the frequency and probability of the appearance of fog, its significant relationship with the circulation was demonstrated. This relationship is so strict that on the basis of the forecasted synoptic situation, the occurrence of fog can be predicted with high probability. The possibility of forecasting the occurrence of fog, its density and the time of retention is an extremely important issue in the context of the safety of crews and passengers as well as aviation tasks.
\end{abstract}


Keywords: fog, atmospheric circulation, airports

Zarys treści: Mgła należy do groźnych zjawisk atmosferycznych, które utrudniają, a czasami nawet uniemożliwiają wykonanie operacji lotniczych. W pracy scharakteryzowano występowanie mgły na 3 lotniskach w południowej Polsce w latach 1981-2010 oraz jej uwarunkowania cyrkulacyjne. Podstawę badań stanowią dane dotyczące występowania dni z mgłą w Balicach, Muchowcu i Jasionce oraz kalendarz typów cyrkulacji Niedźwiedzia (2013). Najwięcej dni z mgłą wystąpiło w Balicach, a najmniej w Muchowcu, co jest uwarunkowane różnym ukształtowaniem terenu. Na wszystkich lotniskach mgła najczęściej pojawiała się jesienią, szczególnie w październiku, a najrzadziej latem z minimum częstości w lipcu. Prawdopodobieństwo wystąpienia mgły w poszczególnych porach roku było silnie zróżnicowane. Największe występuje w typach cyrkulacji bezadwekcyjnych: centrum wyżu $(\mathrm{Ca})$ i klin antycyklonalny (Ka) na wszystkich lotniskach. Spośród typów adwekcyjnych dużą rolę w kształtowaniu mgieł odgrywają typy z sektora południowego. W Balicach najczęściej występują mgły o najkrótszym i najdłuższym czasie trwania, oraz te utrzymujące się minimum dobę. Na pozostałych lotniskach mgła utrzymuje się w przedziale między 6 a 12 godzin.

Stowa kluczowe: mgła, cyrkulacja atmosfery, lotniska

\section{Wstęp}

Wykonywanie tzw. operacji lotniczych jest ściśle zależne od warunków pogodowych. Szereg zjawisk meteorologicznych może utrudniać, a nawet uniemożliwiać wykonanie lotu. Zalicza się do nich: widzialność poziomą, niską podstawę chmur, intensywne opady atmosferyczne, oblodzenie, gołoledź, burzę, turbulencję oraz uskoki wiatru (Domicz, Szutowski 1998). Wymienione zjawiska wraz z parametrami fizycznymi, takimi jak: temperatura powietrza, aktualna zawartość pary wodnej w powietrzu czy ciśnienie atmosferyczne charakteryzują meteorologiczne warunki lotów panujące w przestrzeni powietrznej (Jafernik i in. 2000). Najważniejsza z nich jest widzialność pozioma, która zależy przede wszystkim od występowania mgły. Mgła jest zaliczana do najbardziej groźnych zjawisk meteorologicznych, szczególnie dla transportu powietrznego, ze względu na ograniczoną widzialność do $1 \mathrm{~km}$. Według Stownika meteorologicznego (2003) mgła to zawiesina kropelek wody lub kryształków lodu w przyziemnej warstwie powietrza, która powstaje w wyniku kondensacji pary wodnej. W zależności od czynnika powodującego spadek temperatury w warstwie powietrza przy powierzchni ziemi, wyróżnia się różne typy mgieł. Na obszarze badań występują mgły radiacyjne i adwekcyjne - będące mgłami wewnątrzmasowymi, mgły frontowe, oraz mgły z wyparowania. Spośród wielu typów mgieł szczególnie groźne dla lotnictwa są mgły adwekcyjne oraz radiacyjne. Mgła adwekcyjna powstaje przy napływie stosunkowo ciepłej i wilgotnej masy powietrza nad wychłodzone podłoże, głównie w chłodnej połowie roku. Grubość takiej mgły dzięki przewodnictwu 
turbulencyjnemu może dochodzić nawet do $2 \mathrm{~km}$. Powstaje o każdej porze dnia i nocy, obejmując przy tym rozległe obszary i może się utrzymywać przez kilka dni (Chromow 1977). Mgła radiacyjna powstaje z wypromieniowania ciepła w godzinach nocnych przy pogodzie bezchmurnej lub o niewielkim zachmurzeniu. Latem tego typu mgły są zwykle lokalne, słabo rozciągnięte w pionie i zanikają niedługo po wschodzie słońca (wskutek wyparowania lub cyrkulacji powietrza) (Kożuchowski 2012). W zimie natomiast tworzą się przy pogodzie „wyżowej” (inwersja osiadania), gdy następuje wychładzanie się powietrza w dolnej troposferze, pokrywają znaczny obszar i utrzymują się przez wiele dni (Bajkiewicz-Grabowska, Kossowska-Cezak 2008). Mgły radiacyjne są bardziej gęste przy powierzchni ziemi, dlatego w większym stopniu ograniczają prowadzenie różnego rodzaju operacji lotniczych (Bac, Rojek 1979). Mgły frontowe powstają najczęściej wskutek mieszania się ciepłego i chłodnego powietrza na powierzchniach frontowych (najczęściej frontów ciepłych, tuż przed linią frontu lub tuż po przejściu frontu). Mają zasięg lokalny (Holec, Tymański 1973). Nad zbiornikami wodnymi, rzekami czy podmokłymi gruntami, można dostrzec mgły z wyparowania, również o zasięgu lokalnym, które powstają w wyniku unoszenia się pary wodnej z cieplejszej wody do chłodnego powietrza, którego temperatura jest niższa od temperatury punktu rosy (Kożuchowski 2012).

Celem pracy jest określenie czasowej zmienności występowania mgły oraz warunków cyrkulacyjnych, które sprzyjają jej powstawaniu, na przykładzie trzech wybranych lotnisk w południowej Polsce w latach 1981-2010. Badania wpływu cyrkulacji na występowanie mgły w Polsce przeprowadzili Błaś i Sobik (2004) w latach 1994-2000, Głowacka i in. (2005) w latach 1973-2002, Wiążewski i Bąkowski (2007) w latach 1973-2002 oraz Łupikasza i Niedźwiedź (2016) w latach 1966-2015. We wszystkich tych pracach omawiane było występowanie mgieł, jednak w różnym czasie trwania, co czyni, że uzyskane wyniki są nieporównywalne. Ostatnio Skomorowski i Piotrowski (2018) przedstawili badania dotyczące występowania mgieł w Polsce na 8 lotniskach, z uwzględnieniem czasu trwania zjawiska. Jednak ich wyniki badań odnoszą się do krótkiego okresu (2005-2015). W poniższej pracy wzięto pod uwagę 3 reprezentacyjne lotniska w Polsce południowej, określając częstość, prawdopodobieństwo warunkowe i czas trwania mgły w 30-leciu 1981-2010.

\section{Materiały źródłowe i metoda opracowania}

Materiałem wyjściowym do badań są dni z mgłą oraz czas trwania mgły w ciągu doby na trzech stacjach synoptycznych zlokalizowanych w południowej Polsce: Katowice- Muchowiec $\left(50^{\circ} \mathrm{N} 19^{\circ} \mathrm{E}\right)$, Kraków-Balice $\left(50^{\circ} \mathrm{N} 19^{\circ} \mathrm{E}\right)$ i Rzeszów-Jasionka $\left(50^{\circ} \mathrm{N} 22^{\circ} \mathrm{E}\right)$ (ryc. 1), należących do sieci Instytutu Meteorologii i Gospodarki Wodnej - Państwowy Instytut Badawczy (IMGW-PIB). 
Zgodnie z definicją za dzień z mgłą uznano każdy, w którym niezależnie od terminu obserwacyjnego przynajmniej raz stwierdzono ograniczenie widzialności poziomej poniżej $1 \mathrm{~km}$ z powodu obecności mgły. Przedstawiono zatem przebieg roczny i wieloletni występowania dni z mgłą na trzech wybranych lotniskach, a także czas trwania zjawiska. Wieloletnią zmienność przedstawiono za pomocą trendów zmian liczby dni z mgłą w porach roku w przyjętym do badań 30-leciu 1981-2010 na podstawie równania regresji liniowej. Do określenia związku występowania mgły z cyrkulacją atmosfery wykorzystano Kalendar sytuacji synoptycznych doræecza górnej Wisty autorstwa T. Niedźwiedzia (2013). Związek występowania dnia z mgłą z typami cyrkulacji określono prawdopodobieństwem warunkowym. Prawdopodobieństwo warunkowe w ogólnej postaci wyraża formuła:

$$
P(B / A)=\frac{P(A \cap B)}{P(A)} 100[\%]
$$

gdzie:

P - prawdopodobieństwo zajścia określonego zdarzenia losowego B pod warunkiem zajścia innego zdarzenia losowego A (Koronacki, Mielniczuk 2001).

\section{Uwarunkowania lokalne}

Rozwój mgieł zależy nie tylko od cyrkulacji atmosfery, ale również od warunków lokalnych (ukształtowanie terenu, odległość od zbiorników wodnych, występowanie szaty roślinnej). Wybrane lotniska są zlokalizowane na przedpolu Karpat Zachodnich, z wyjątkiem lotniska Katowice-Muchowiec, które znajduje się w obrębie Wyżyny Katowickiej i leży najwyżej spośród badanych lotnisk (277 m n.p.m.) (ryc. 1). Muchowiec jest jednym z trzech lotnisk zlokalizowanych zaledwie 2,5 km od centrum miasta. Według Landsberga (1973) wpływ miejskiej wyspy ciepła oraz zanieczyszczeń powietrza może przekładać się na wzrost częstości występowania mgły w mieście. Obszar charakteryzuje się stosunkowo łagodnym ukształtowaniem terenu, a na mgłę narażone są przede wszystkim wklęsłe formy terenu oraz tereny pokryte roślinnością (Las Murckowski czy Panewnicki) (Cabała 1999).

Port Lotniczy Kraków-Balice leży 58 km na wschód od lotniska w Muchowcu, znajduje się na północy mezoregionu Obniżenia Cholerzyńskiego, na wysokości 241 m n.p.m. (tab. 1, ryc. 1). Lotnisko leży w obrębie dna Rowu Krzeszowickiego oraz doliny Rudawy, przez co znajduje się w zasięgu mezoklimatu den dolinnych o dużych dobowych kontrastach termiczno-wilgotnościowych z bardzo częstym powstawaniem zastoisk zimnego powietrza. Przewietrzanie obszaru jest słabe lub umiarkowane, co warunkuje skłonność do powstawania mgieł (Nowak 1968). 

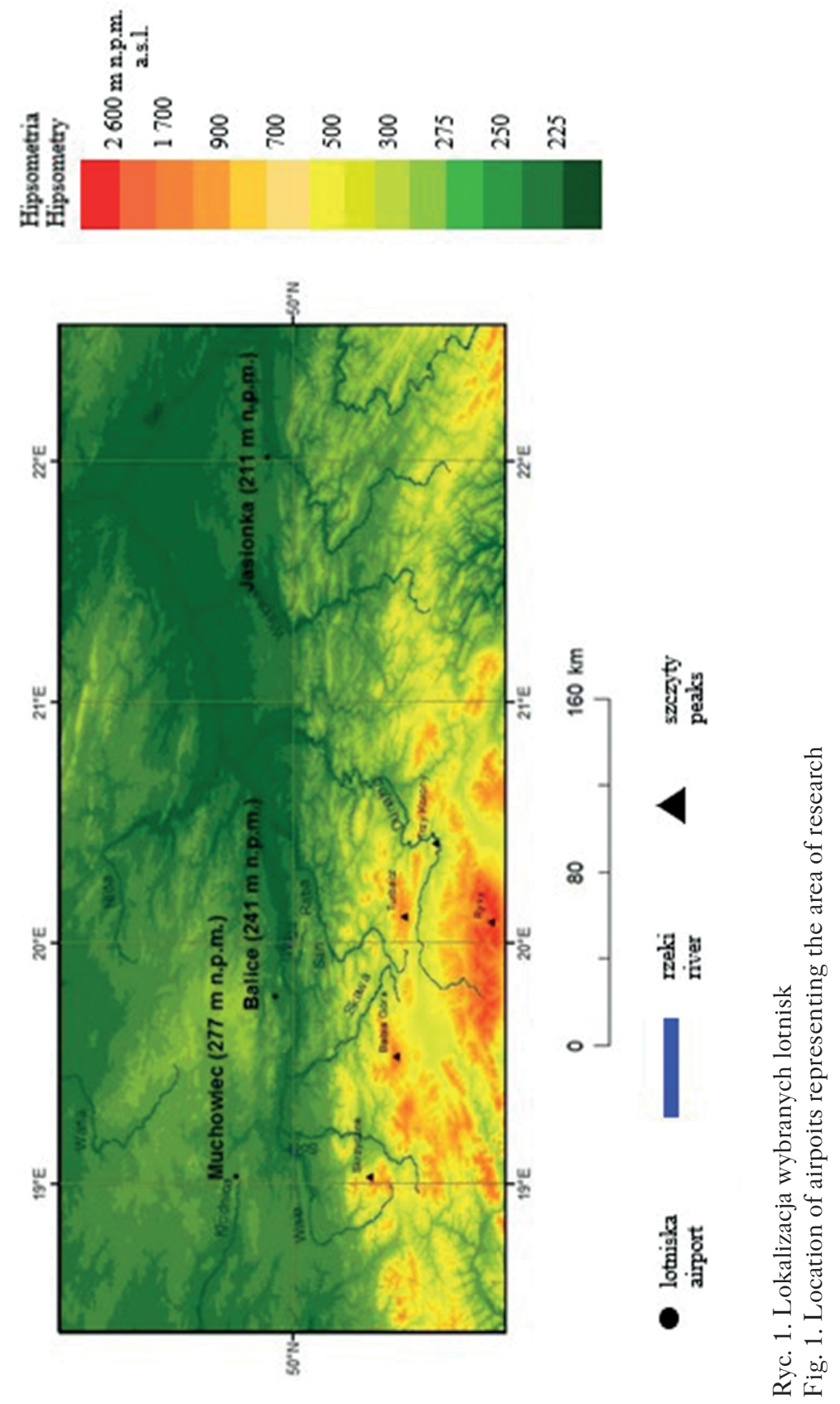
Tab. 1. Stacje synoptyczne IMGW-PIB wykorzystane w opracowaniu Table 1. Synoptic stations of IMGW-PIB used in the study

\begin{tabular}{|c|c|c|c|c|}
\hline $\begin{array}{c}\text { Numer WM0 } \\
\text { WM0 number }\end{array}$ & $\begin{array}{c}\text { Stacja } \\
\text { Station name }\end{array}$ & $\begin{array}{c}\text { Współrzędne } \\
\text { geograficzne } \\
\text { Geographical } \\
\text { coordinates }\end{array}$ & $\begin{array}{c}\text { Wysokość (m n.p.m.) } \\
\text { Altitude (m. a.s.l.) }\end{array}$ & $\begin{array}{c}\text { Forma terenu } \\
\text { Landform }\end{array}$ \\
\hline 12560 & Katowice-Muchowiec & $50^{\circ} \mathrm{N} 19^{\circ} \mathrm{E}$ & 277 & Wyżyna Katowicka \\
\hline 12566 & Kraków-Balice & $50^{\circ} \mathrm{N} 19^{\circ} \mathrm{E}$ & 241 & Obniżenie Cholerzyńskie \\
\hline 12580 & Rzeszów-Jasionka & $50^{\circ} \mathrm{N} 22^{\circ} \mathrm{E}$ & 211 & $\begin{array}{c}\text { Bruzda Pradoliny } \\
\text { Podkarpackiej }\end{array}$ \\
\hline
\end{tabular}

Trzecie lotnisko Rzeszów-Jasionka, znajduje się 214 km na wschód od Katowic i $159 \mathrm{~km}$ na wschód od Balic. Znajduje się w południowej części Kotliny Sandomierskiej, rozległego zapadliska tektonicznego w obrębie bruzdy Pradoliny Podkarpackiej (Kondracki, 2000), ponadto jest najniżej położonym lotniskiem spośród dwóch pozostałych (211 m n.p.m.) (tab. 1, ryc. 1) i leży w otoczeniu Podkarpackiego Parku Naukowo-Technologicznego Aeropolis.

\section{Częstość dni z mgłą w ciągu roku}

Z dotychczasowych badań (Błaś, Sobik 2004; Woś, 2010; Skomorowski, Piotrowski, 2018) wiemy, że rozkład przestrzenny rocznej liczby dni z mgłą w Polsce jest bardzo zmienny i silnie zależy od czynników lokalnych, w szczególności od ukształtowania terenu i lokalizacji zbiorników wodnych (morze, jeziora). Najwyższa częstość mgły występuje w Karpatach i Sudetach. Średnia roczna liczba dni z mgłą zmienia się wraz z wysokością. W Karpatach Zachodnich wzrasta ona znacznie od około 100 dni przy 1000 m n.p.m. do ponad 250-290 dni na grzbietach tatrzańskich (Błaś i Sobik, 2004; Woś, 2010). Na nizinach średnia roczna liczba dni z mgłą waha się od 40 do 60 dni (Piwkowski 1976; Woś 2010). Tylko na pomorskim regionie jeziornym w północnej Polsce i kilku wklęsłych formach terenu częstość mgły przekracza 70 dni.

W południowej Polsce w latach 1981-2010 liczba dni z mgłą w roku waha się od 56 w Muchowcu do 66 w Balicach. Roczna liczba dni z mgłą w Balicach, lotnisku zlokalizowanym w Obniżeniu Cholerzyńskim, jest o 10 dni wyższa niż w Muchowcu położonym na Pogórzu Śląskim i o 8 wyższa niż w Jasionce położonej w bruździe Pradoliny Podkarpackiej. Zgodnie z oczekiwaniem najczęściej mgła występuje jesienią z maksimum przypadającym na październik (8-10 dni) (tab. 2). Niewiele mniej dni z mgłą występuje zimą. W Balicach średnia liczba dni z mgłą w tej porze 
Tab. 2. Średnia liczba dni z mgłą na analizowanych lotniskach (1981-2010) Table 2. Average number of days with fog at analysed airports (1981-2010)

\begin{tabular}{|c|c|c|c|c|c|c|c|c|c|c|c|c|c|c|c|c|c|}
\hline $\begin{array}{c}\text { Lotnisko } \\
\text { Airport }\end{array}$ & I & II & III & IV & V & VI & VII & VIII & IX & X & XI & XII & XII-II & III-V & VI-VII & IX-XI & $\begin{array}{c}\text { Rok } \\
\text { Year }\end{array}$ \\
\hline Muchowiec & 5,8 & 5,0 & 3,8 & 3,3 & 2,5 & 2,5 & 1,8 & 2,5 & 5,3 & 8,3 & 8,2 & 7,2 & 18,1 & 9,7 & 6,9 & 21,8 & 56,4 \\
\hline Balice & 6,7 & 4,5 & 4,4 & 3,0 & 3,0 & 2,8 & 2,0 & 3,6 & 6,8 & 10,0 & 9,7 & 9,1 & 20,3 & 10,4 & 8,4 & 26,5 & 65,6 \\
\hline Jasionka & 4,3 & 4,4 & 3,8 & 3,4 & 3,7 & 3,7 & 3,1 & 5,5 & 6,9 & 8,1 & 6,4 & 4,8 & 13,5 & 10,9 & 12,3 & 21,4 & 58,0 \\
\hline
\end{tabular}

Objaśnienia: Kolorem jasnoszarym zaznaczono najmniejszą średnią miesięczną liczbę dni z mgłą, zaś ciemnoszarym największą średnią miesięczną liczbę dni z mgłą w przebiegu rocznym.

Explanations: The lowest mean annual number of days with fog occurence in light gray, the highest mean annual number - in dark grey.

roku przekracza 20, w Muchowcu 18, a w Jasionce 14 dni, z maksimum przypadającym na grudzień. Jesienią i zimą tworzeniu mgły sprzyjają rozległe wyże z centrum nad środkową Europą. Korzystny jest również napływ cieplejszych mas powietrza z południa lub zachodu kontynentu. Jesienią dominują głównie mgły adwekcyjne, zimą również radiacyjne, w czasie tzw. pogody „wyżowej”. Najrzadziej mgła występuje latem, średnia liczba dni z mgłą waha się od 12 dni w Jasionce do 7 dni w Muchowcu. Najmniej dni z mgłą przypada na lipiec (tab. 2). Wyniki te potwierdziły wcześniej przeprowadzone badania przez Błasia i Sobika (2004) oraz Łupikaszę i Niedźwiedzia (2016). Wiosną i latem występują głównie mgły radiacyjne i frontowe. Najrzadziej występują mgły z wyparowania, tworzące się nad powierzchniami zielonymi czy zbiornikami wodnymi. Wartości te zatem dowodzą o wiodącej roli ukształtowania terenu. Duża częstość występowania mgieł w Balicach jesienią i zimą związana jest z lokalizacją lotniska w zagłębieniu, co sprzyja występowaniu głównie mgieł radiacyjnych. Natomiast wiosną i latem niewiele więcej mgieł występuje w Jasionce niż w Balicach, co może być związane z częstszym występowaniem mgieł frontowych.

\section{Przebieg wieloletni rocznej liczby dni z mgłłą}

Występowanie mgły na wybranych lotniskach charakteryzuje się dużą zmiennością w 30-leciu. W badanym 30-leciu 1981-2010 największy spadek liczby dni z mgłą w ciągu roku występuje w Balicach, w Jasionce i jest on istotny statystycznie na poziomie 0,05. W 10-leciu 2001-2010 średnia roczna liczba dni z mgłą spadła o ponad 20 dni w Balicach, a w Jasionce o 16 dni w stosunku do 10-lecia 1981-1990. 
Natomiast w Muchowcu tendencja liczby dni z mgłą w 30-leciu nie wykazuje istotnych zmian (średnio 56 dni) (ryc. 2). Warto zwrócić uwagę na lata 1981-1985, a w szczególności rok 1982, które charakteryzowały się dużą liczbą dni z mgłą. Tak dużą różnicę można wytłumaczyć wysoką koncentracją zanieczyszczeń powietrza, co sprzyja występowaniu mgły (Łupikasza, Niedźwiedź 2016). Znajdujące się na wyższej wysokości lotnisko w Muchowcu charakteryzuje się mniejszą liczbą dni z mgłą, ze względu na niższe stężenia zanieczyszczeń i lepsze warunki wentylacji, które są niekorzystne dla występowania mgły. Podobną sytuację zauważyła Morawska (1966) w latach 1957-1966 na lotnisku w Balicach, gdzie duża częstość występowania mgły (81-130 dni) była spowodowana wysoką koncentracją zanieczyszczeń powietrza.

Przebieg występowania mgły na rozpatrywanych lotniskach jest zróżnicowany w ciągu roku. Największy spadek liczby dni z mgłą wystąpił w lecie i jest on istotny statystycznie na wszystkich lotniskach. Wiosną spadek istotny statystycznie liczby dni z mgłą wystąpił w Jasionce (4 dni) i w Balicach (3 dni). W Muchowcu zaś nie wykazał istotnych zmian (ryc. 3). W latach 1966-2015 Łupikasza i Niedźwiedź (2016) zaobserwowali podobną sytuację na lotnisku w Balicach oraz w Muchowcu i stwierdzili, że tendencja spadkowa może być związana ze wzrostem temperatury powietrza. W zimie oraz w jesieni spadek liczby dni z mgłą istotny statystycznie występuje tylko w Balicach. Na dwóch pozostałych lotniskach trendy nie były istotne statystycznie (ryc. 3), co również potwierdziły wcześniej prowadzone badania Łupikaszy i Niedźwiedzia (2016). W Muchowcu trend wykazał tendencję wzrostową zarówno zimą, jak i jesienią, natomiast w Jasionce był stały (ryc. 3).

\section{Prawdopodobieństwo wystąpienia mgły}

Występowanie mgieł jest silnie powiązane z cyrkulacją atmosferyczną, a relacje te charakteryzuje wyraźna zmienność sezonowa. W opracowaniach klimatologicznych sama częstość danego zjawiska nie oddaje rzeczywistego wpływu cyrkulacji atmosferycznej. Według Łupikaszy i Niedźwiedzia (2016) mgła najcześciej wystepuje w typach antycyklonalnych, a najbardziej sprzyjają jej sytuacje bezadwekcyjne, głównie klin antycyklonalny (Ka). Spośród typów adwekcyjnych dużą rolę w kształtowaniu mgieł odgrywają sytuacje przy napływie powietrza z południa. Jednak udział poszczególnych typów cyrkulacji jest bardzo zróżnicowany. Zatem lepszym rozwiązaniem jest przedstawienie częstości względnej.

W zimie największe prawdopodobieństwo wystąpienia mgły występuje w typie SWa w Balicach $(52,6 \%)$, podczas gdy na pozostałych lotniskach prawdopodobieństwo jest o połowę mniejsze. Spośród typów adwekcyjnych dużą rolę w kształtowaniu mgieł odgrywają typy Sa i Sc w Balicach, oraz Sc w Muchowcu, przy których 

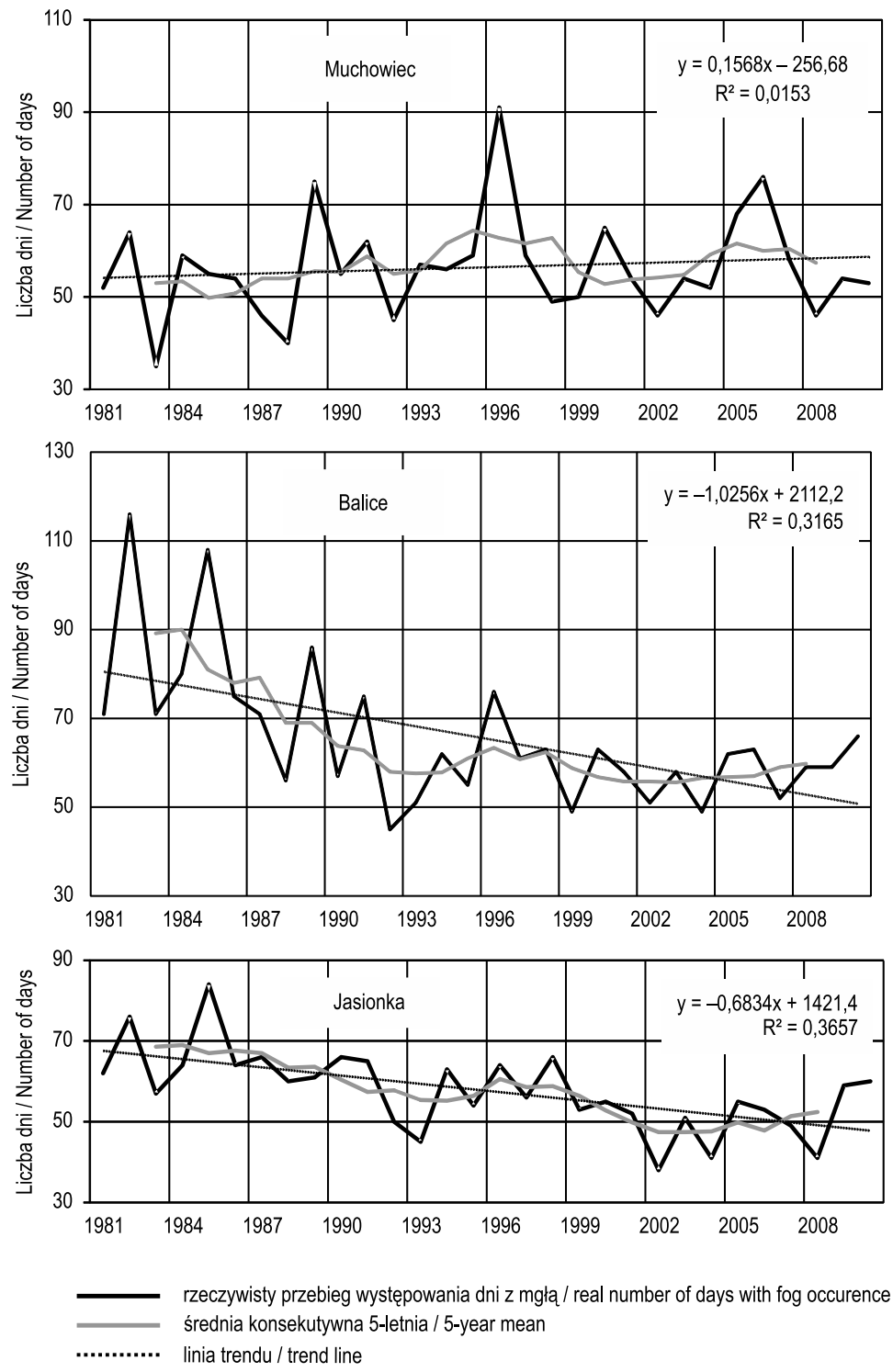

Ryc. 2. Wieloletni przebieg występowania dni z mgłą na wybranych lotniskach (1981-2010) Fig. 2. Annual distribution of days with fog occurrence at selected airports (1981-2010) Źródto: opracowanie własne na podstawie danych IMGW-PIB.

Source: author's own elaboration based on IMGW-PIB data. 

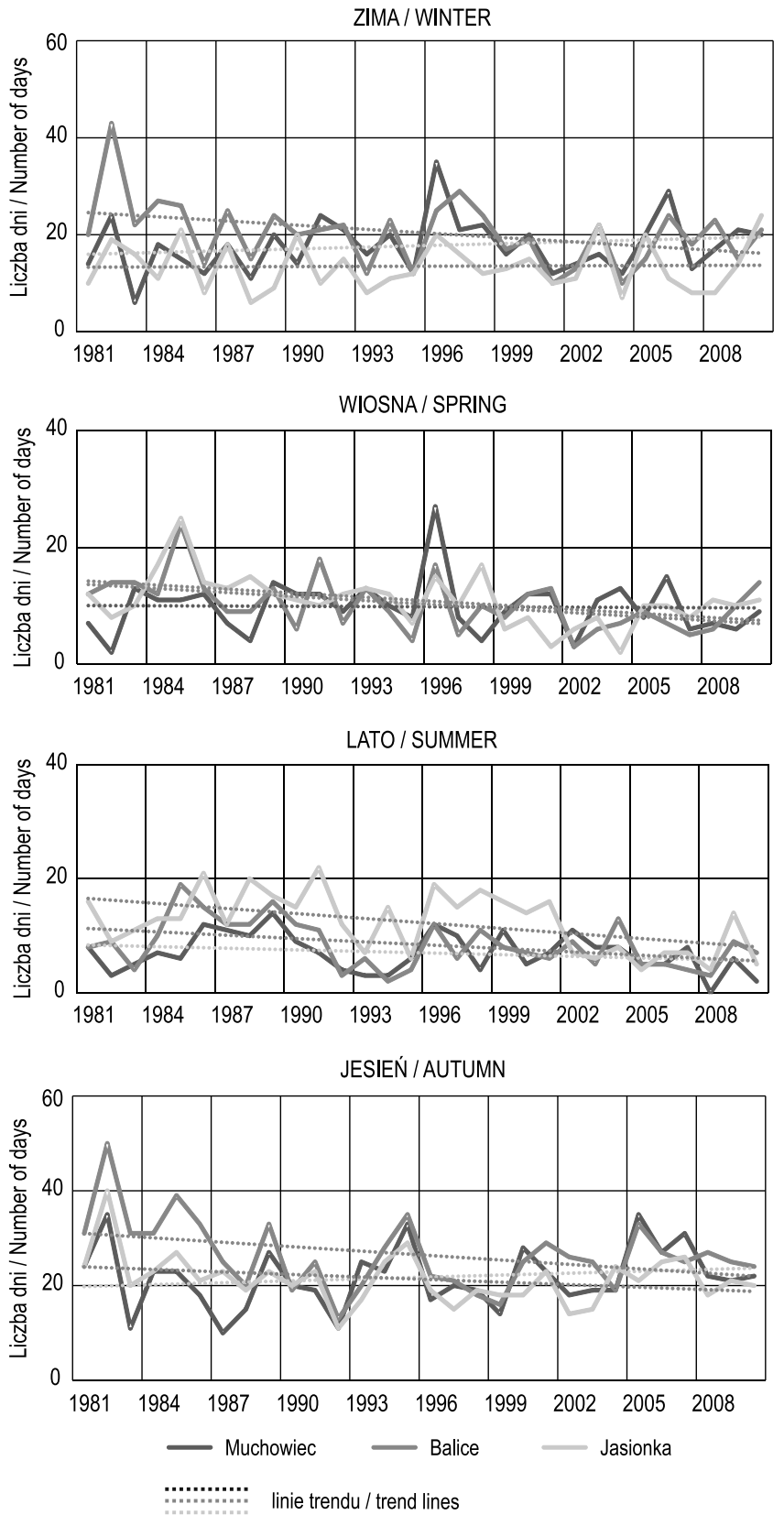

Ryc. 3. Wieloletni przebieg występowania dni z mgłą w sezonach na wybranych lotniskach (1981-2010)

Fig. 3. Annual seasonal distribution of days with fog at selected airports (1981-2010) Źródto: opracowanie własne na podstawie danych IMGW-PIB.

Source: author's own elaboration based on data IMGW-PIB data. 

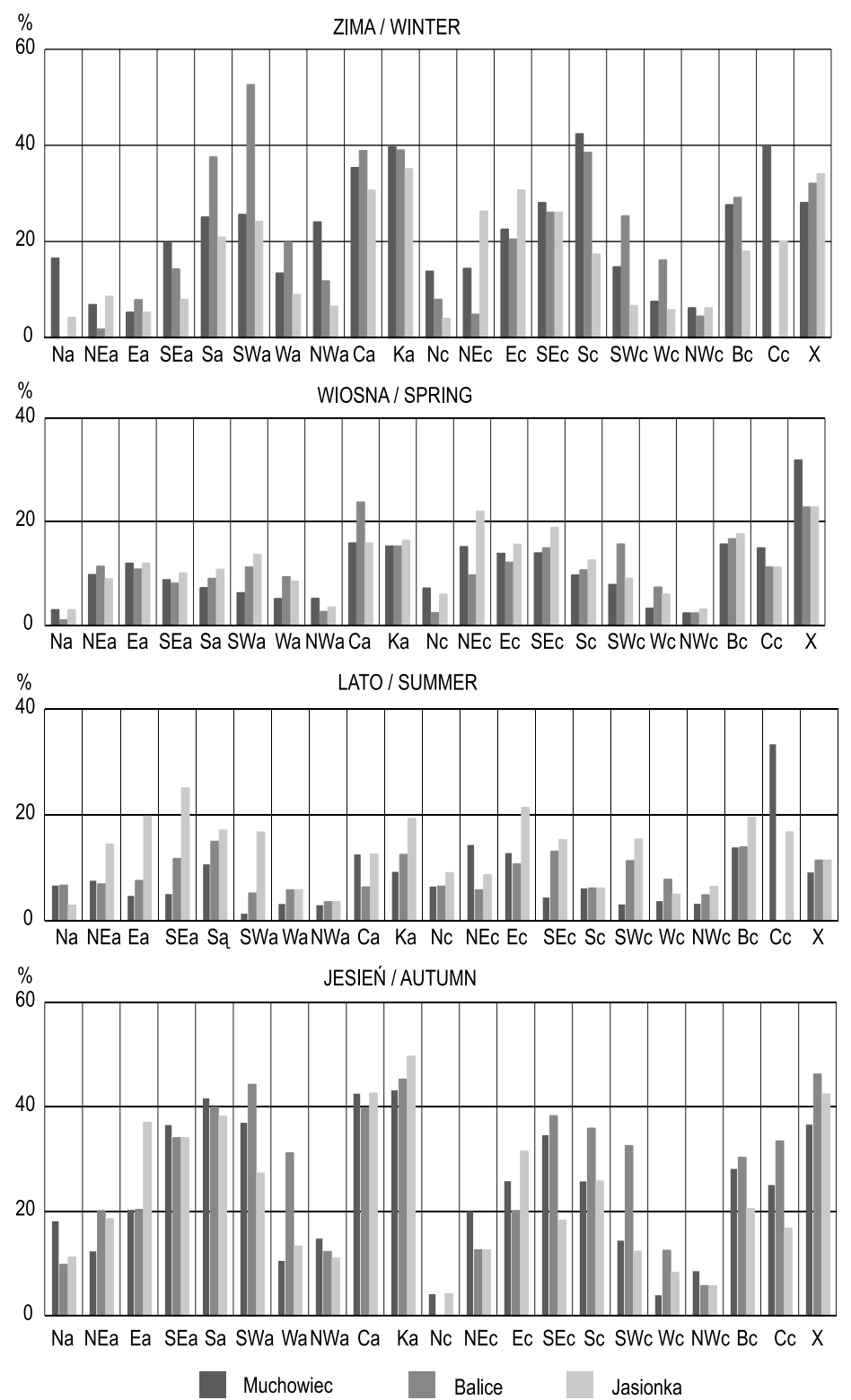

Ryc. 4. Prawdopodobieństwo warunkowe [\%] wystąpienia dnia z mgłą w poszczególnych typach cyrkulacji wg kalendarza Niedźwiedzia (2013) na lotniskach: Katowice-Muchowiec, Kraków-Balice, Rzeszów-Jasionka, w wieloleciu 1981-2010

Fig. 4. Conditional probability [\%] of the day with fog occurrence in particular types of circulation by Niedzwiedź (2013) in winter, spring, summer and autumn at the airport: Katowice-Muchowiec, Krakow-Balice, Rzeszow-Jasionka (1981-2010) 
prawdopodobieństwo wynosi ok. 40\% (ryc. 4). W Muchowcu znaczną rolę odgrywa również prawdopodobieństwo wystąpienia mgły w typie Cc, również 40\%. Zgodnie z oczekiwaniem duże prawdopodobieństwo wystąpienia dnia z mgłą występuje w typach cyrkulacji bezadwekcyjnych - centrum wyżu (Ca), i klin antycyklonalny (Ka) na wszystkich lotniskach (31-40\%) (ryc. 4). W takich warunkach cyrkulacyjnych tworzą się mgły radiacyjne, które są dominującym typem mgieł w południowej Polsce.

Wiosną i latem prawdopodobieństwo wystąpienia mgły jest najmniejsze. Tylko w pięciu typach przekracza ona $20 \%$. Wiosną zdarzyło się to dwukrotnie w typach $\mathrm{Ca}(24 \%)$ w Balicach i NEc (22\%) w Jasionce. Latem natomiast w Jasionce w typach SEa (25\%) i Ec (21\%) oraz w Muchowcu w typie Cc (33\%) (ryc. 4). Sprzyja to tworzeniu się mgieł adwekcyjnych, czasem frontowych.

Jesienią w porównaniu z pozostałymi porami roku występuje największe prawdopodobieństwo dnia z mgłą. W typach bezadwekcyjnych: Ka i Ca na wszystkich trzech rozpatrywanych lotniskach prawdopodobieństwo jest największe i przekracza 40\%, z maksimum w Jasionce 50\% w typie Ka. Niewiele mniejsze prawdopodobieństwo występuje przy typach z sektora południowego SEa, Sa, SWa bez udziału adwekcji (27-44\%) (ryc. 4). Znaczny udział występowania mgieł przypada również na typy Ccsytuacja centralna cyklonalna i Bc - bruzda cyklonalna lub rozmyty obszar niskiego ciśnienia, w szczególności w Balicach ok. 35\% (ryc. 4). W takich warunkach tworzą się mgły adwekcyjne, a także podobnie jak zimą mgły radiacyjne.

Prawdopodobieństwo wystąpienia mgieł jest większe zimą i jesienią w typach antycyklonalnych, a wiosną i latem w typach cyklonalnych. We wszystkich porach roku największe prawdopodobieństwo przypada na typy bezadwekcjne Ca i Ka. Wyjątkowo niskim prawdopodobieństwem wystąpienia mgły charakteryzowały się typy związane z napływem powietrza z północy, północo-wschodu i północo-zachodu.

\section{Czas trwania mgły}

W prowadzeniu wszelkich operacji lotniczych istotne jest określenie czasu trwania zjawisk, które mogą je destabilizować. W przypadku pojawienia się mgły służby meteorologiczne są zobowiązane wydać specjalny komunikat dotyczący czasu jej trwania oraz stopnia ograniczenia widzialności poziomej na terenie lotniska.

Analiza częstości mgły o różnym czasie trwania wskazuje na decydującą rolę ukształtowania terenu danego lotniska. Mgły o krótkim czasie trwania najczęściej występują w Balicach (tab. 3). Lotnisko znajduje się w zasięgu mezoklimatu den dolin, z częstym powstawaniem zastoisk zimnego powietrza, co powoduje powstanie mgieł głównie we wczesnych godzinach porannych. Związane jest to również ze słabszym przewietrzaniem, co przekłada się na występowanie cisz atmosferycznych, których największa częstość przypada na godziny wieczorne i poranne 
(Matuszko i in. 2005). Mgły o różnym czasie trwania wykazują podobną częstość (tab. 3). Może to wynikać z czynników lokalnych, jak i cyrkulacyjnych. Wykazali to w swoich badaniach również Skomorowski i Piotrowski (2018).

Analizie poddano również przypadki całodobowego występowania mgły. Najwięcej takich przypadków wystąpiło w Balicach (18), zdecydowanie mniej w Muchowcu (4) i Jasionce (8). Jak już stwierdzono, w Balicach dominuje mgła o genezie radiacyjnej z najkrótszym czasem trwania, ale również wspomniane przypadki z mgłą całodobową. Co więcej, wystąpiły również dwa epizody, w których mgła utrzymywała się przez 48 godzin (tab. 4). Wystąpiły one 4 i 5 grudnia 1984 r. oraz 5 i 6 grudnia 2000 r. W czasie trwania tych epizodów pogoda na poszczególnych lotniskach była podobna: brak zachmurzenia frontowego, niska temperatura, brak opadu atmosferycznego oraz słaby wiatr. Przykładowo 6 i 7 grudnia 2000 r. Europa Zachodnia znajdowała się w zasięgu rozległego niżu znad Oceanu Atlantyckiego. Wschodnia część Europy wraz z Polską znajdowała się w zasięgu wyżu z centrum nad południowo-wschodnią Ukrainą. Szczegółowa analiza map wskazuje, że wyż ten miał charakter układu blokującego. Stosunkowo mały gradient ciśnienia nad obszarem południowej Polski przyczyniał się do stagnacji mas powietrza, utrwalenia warunków ujemnego bilansu radiacyjnego i w efekcie doprowadził do długotrwałego zalegania gęstej mgły (ryc. 5, 6).

Największa w roku liczba dni z mgłą w Balicach powoduje, że to lotnisko charakteryzuje się największym zagrożeniem dla płynności prowadzenia ruchu lotniczego. Odpowiada za to położenie lotniska w obrębie wklęsłej formy terenu, tj. Obniżenia Cholerzyńskiego, cechującego się tendencją do tworzenia zastoisk chłodnego powietrza oraz przyziemnych inwersji temperatury. Obszar ten wyróżnia się również słabą wentylacją, a udział cisz i wiatrów słabych (do $\left.1 \mathrm{~m} \cdot \mathrm{s}^{-1}\right)$ stanowi przeszło $40 \%$ liczby dni w ciągu roku.

Tab. 3. Częstość (\%) mgły o rożnym czasie trwania (w godz.) w latach 1981-2010 Table 3. Frequency (\%) of fog with different duration (in hours) in 1981-2010

\begin{tabular}{|c|c|c|c|}
\hline $\begin{array}{c}\text { Czas trwania (w godz.) } \\
\text { Duration (in hour) }\end{array}$ & Muchowiec & Balice & Jasionka \\
\hline $0-1 \mathrm{~h}$ & 3,1 & 20,3 & 3,3 \\
\hline $1,1-3 \mathrm{~h}$ & 15,5 & 19,9 & 18,1 \\
\hline $3,1-6 \mathrm{~h}$ & 27,0 & 19,4 & 29,0 \\
\hline $6,1-12 \mathrm{~h}$ & 34,1 & 20,2 & 33,1 \\
\hline $12,1-24 \mathrm{~h}$ & 20,3 & 20,2 & 16,5 \\
\hline
\end{tabular}

Źródto: opracowanie własne na podstawie danych IMGW-PIB.

Source: author's own elaboration based on IMGW-PIB data. 
Tab. 4. Daty wystąpienia mgły całodobowej na analizowanych lotniskach

Table 4. Dates with 24-hour fog occurrence at analysed airports

\begin{tabular}{|c|c|c|c|c|c|c|}
\hline $\begin{array}{l}\text { Rok } \\
\text { Year }\end{array}$ & $\begin{array}{l}\text { Miesiąc } \\
\text { Month }\end{array}$ & $\begin{array}{l}\text { Dzień } \\
\text { Day }\end{array}$ & Muchowiec & Balice & Jasionka & $\begin{array}{c}\text { Typ cyrkulacji } \\
\text { Type of circulation }\end{array}$ \\
\hline 1981 & 12 & 24 & & $\mathrm{M}$ & & NEa \\
\hline 1982 & 1 & 22 & & $\mathrm{M}$ & & $\mathrm{Ka}$ \\
\hline 1982 & 10 & 28 & & $\mathrm{M}$ & & $\mathrm{Ca}$ \\
\hline 1983 & 11 & 08 & & & M & $\mathrm{Ka}$ \\
\hline 1984 & 01 & 30 & M & & & Ka \\
\hline 1984 & 12 & 04 & M & $\mathrm{M}$ & & SEa \\
\hline 1984 & 12 & 05 & & $\mathrm{M}$ & & $\mathrm{Ka}$ \\
\hline 1984 & 12 & 20 & & $\mathrm{M}$ & & SWa \\
\hline 1985 & 1 & 8 & & M & & $\mathrm{Ka}$ \\
\hline 1985 & 3 & 8 & & M & & $x$ \\
\hline 1985 & 12 & 25 & & $\mathrm{M}$ & & SWc \\
\hline 1986 & 11 & 29 & & $\mathrm{M}$ & & $\mathrm{Ca}$ \\
\hline 1987 & 01 & 21 & $\mathrm{M}$ & & & $\mathrm{Ka}$ \\
\hline 1988 & 12 & 03 & & & $\mathrm{M}$ & SEc \\
\hline 1990 & 01 & 16 & M & & & Wa \\
\hline 1991 & 11 & 27 & & $\mathrm{M}$ & & Ka \\
\hline 1992 & 12 & 16 & & $\mathrm{M}$ & & SWa \\
\hline 1995 & 11 & 25 & & $M$ & & SWa \\
\hline 1996 & 12 & 06 & & & M & $\mathrm{Ka}$ \\
\hline 1996 & 12 & 10 & & & $\mathrm{M}$ & Sa \\
\hline 1998 & 11 & 13 & & & $\mathrm{M}$ & $\mathrm{Ka}$ \\
\hline 1999 & 01 & 19 & & & $\mathrm{M}$ & $\mathrm{Ka}$ \\
\hline 1999 & 01 & 20 & & $\mathrm{M}$ & & SWa \\
\hline 2000 & 12 & 06 & & M & $\mathrm{M}$ & SWa \\
\hline 2000 & 12 & 07 & & M & & SWa \\
\hline 2003 & 01 & 25 & & & $\mathrm{M}$ & $\mathrm{Ka}$ \\
\hline 2006 & 11 & 28 & & M & & $\mathrm{Ka}$ \\
\hline 2008 & 1 & 14 & & M & & SWa \\
\hline
\end{tabular}

Objaśnienia: M - całodobowe wystąpienie mgły. Kursywą zaznaczono te dni, w których mgła na lotniskach utrzymywała się przez 48 godzin.

Explanations: M - 24-hour fog occurence. In italic, days with 48-hour fog occurence.

Źródto: opracowanie własne na podstawie danych IMGW-PIB.

Source: authors' own elaboration based on IMGW-PIB data. 


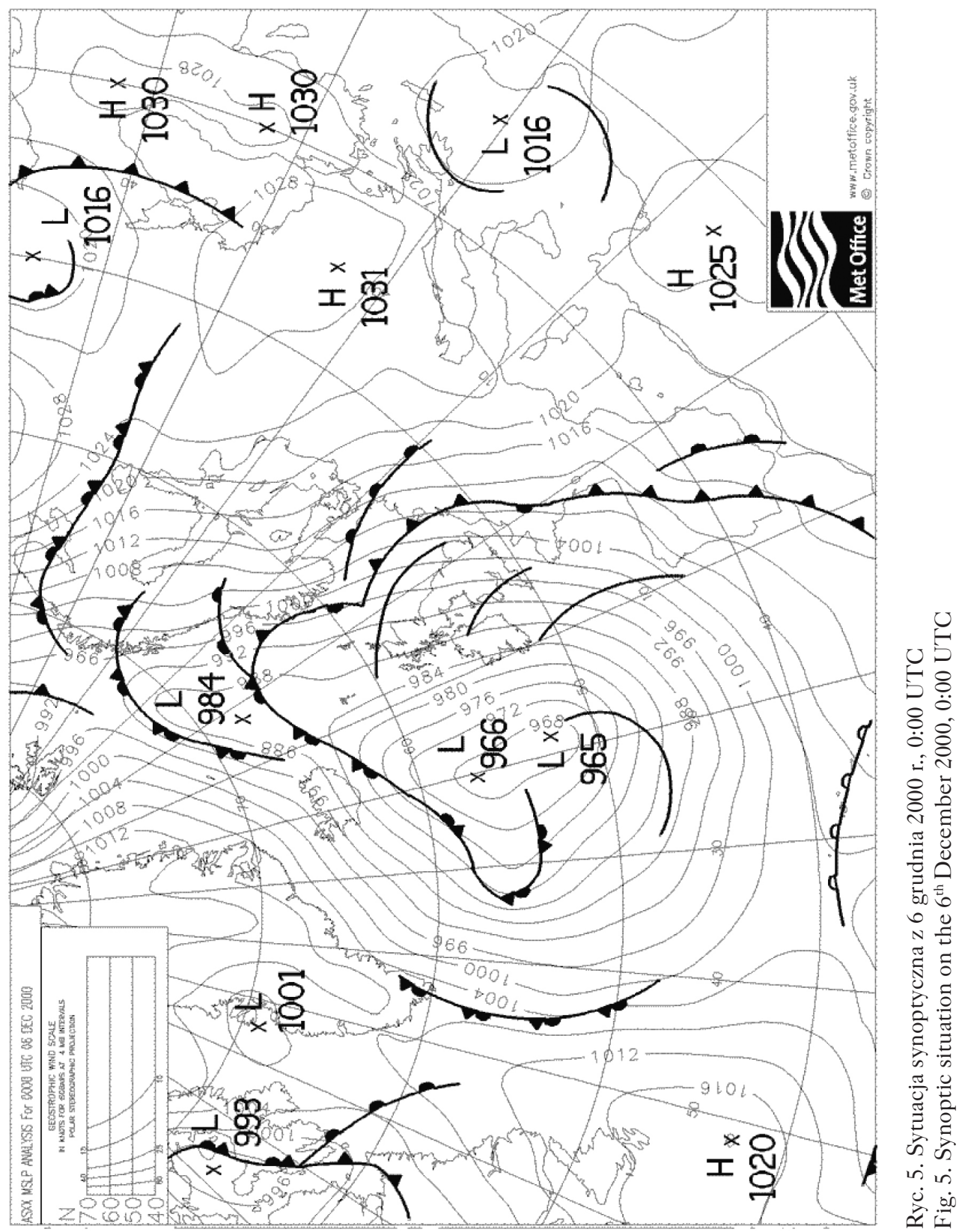




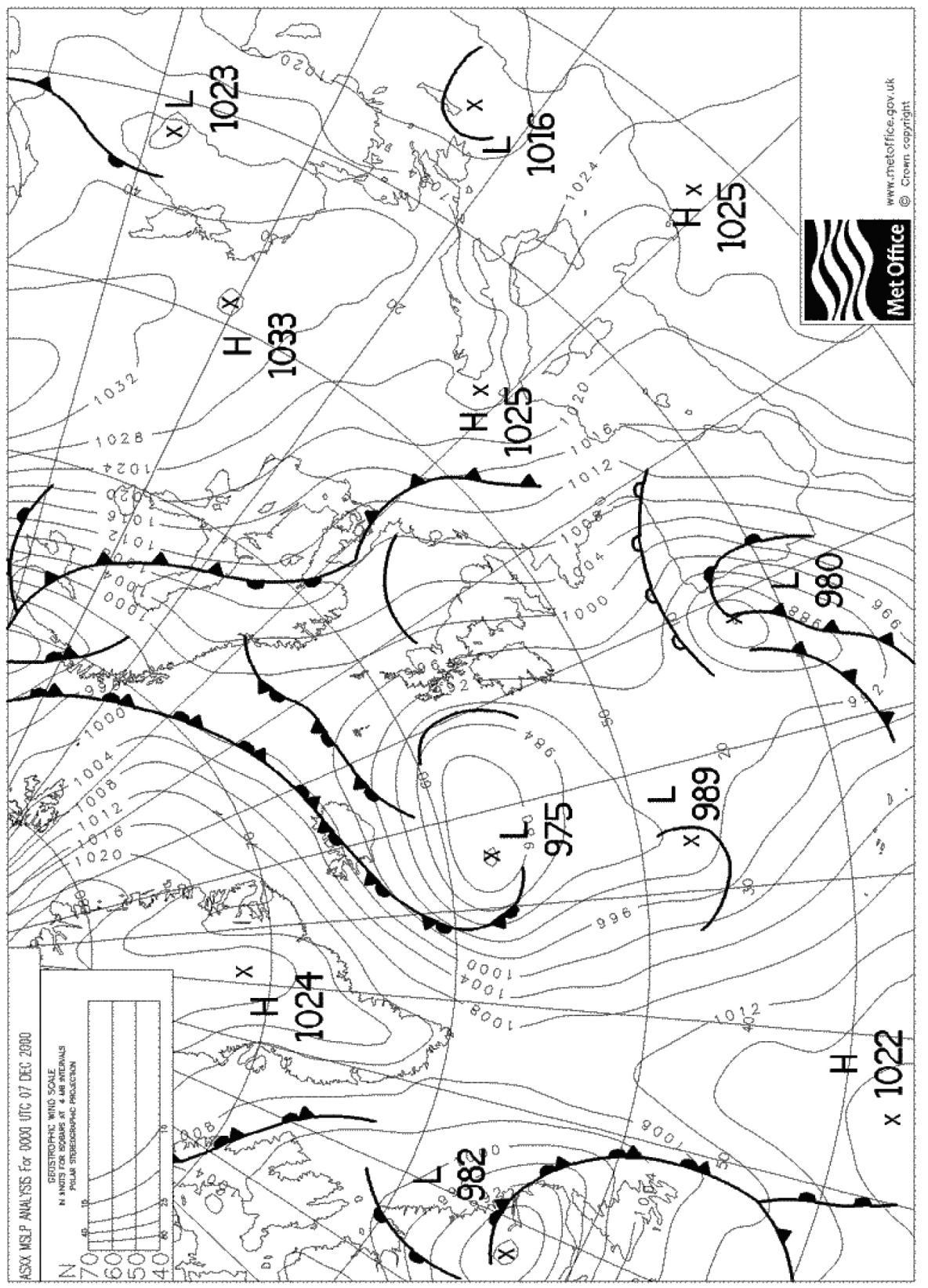

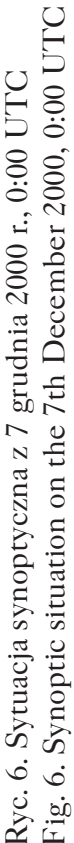




\section{Wnioski}

W artykule omówiono przebieg roczny oraz wieloletni występowania dni z mgłą na trzech wybranych lotniskach oraz ich związek z cyrkulacją atmosferyczną. Mgła jest zjawiskiem stosunkowo częstym - jest notowana około 60 dni w roku. Występowaniem mgły najbardziej jest zagrożone lotnisko Kraków-Balice, a najmniej Katowice-Muchowiec. Mgła występowała najczęściej jesienią, a najrzadziej latem.

W ciągu 30-lecia 1981-2010 największy spadek liczby dni z mgłą w ciągu roku występuje w Balicach, w Jasionce i jest on istotny statystycznie. Natomiast w Muchowcu tendencja liczby dni z mgłą w 30-leciu nie wykazuje znacznych zmian. Przebieg występowania mgły na rozpatrywanych lotniskach jest zróżnicowany w ciągu roku. Największy spadek liczby dni z mgłą wystąpił w lecie i jest on istotny statystycznie na wszystkich lotniskach. W zimie oraz w jesieni spadek liczby dni z mgłą istotny statystycznie występuje tylko w Balicach. Znajdujące się na wyższej wysokości lotnisko w Muchowcu charakteryzuje się mniejszą liczbą dni z mgłą, ze względu na niższe stężenia zanieczyszczeń i lepsze warunki wentylacji, które są niekorzystne dla występowania mgły. Natomiast wielu autorów podkreśla, że w Balicach duża częstość występowania mgły jest spowodowana wysoką koncentracją zanieczyszczeń powietrza.

Prawdopodobieństwo wystąpienia mgły jest największe jesienią i zimą. Spośród typów adwekcyjnych dużą rolę w kształtowaniu mgieł odgrywają typy z sektora południowego. Największe prawdopodobieństwo wystąpienia dnia z mgłą występuje w typach cyrkulacji bezadwekcyjnych - centrum wyżu $(\mathrm{Ca})$ i klin antycyklonalny (Ka) na wszystkich lotniskach. W takich warunkach cyrkulacyjnych tworzą się mgły radiacyjne, które są dominującym typem mgieł w południowej Polsce. Wiosną i latem prawdopodobieństwo wystąpienia mgły jest najmniejsze. Dominują wtedy mgły w typach cyklonalnych. Sprzyja to tworzeniu się mgieł adwekcyjnych, czasem frontowych. Wyjątkowo niskim prawdopodobieństwem wystąpienia mgły charakteryzowały się typy związane z napływem powietrza z północy, północo-wschodu i północo-zachodu.

Analiza potwierdza, że czas trwania mgły zależy od uwarunkowań lokalnych. Mgły o krótkim czasie trwania najczęściej występują głównie w Balicach, natomiast mgły o różnym czasie trwania wykazują podobną częstość na wszystkich rozpatrywanych lotniskach. Najwięcej przypadków całodobowego wystąpienia mgły występuje również w Balicach, co powoduje, że lotnisko to charakteryzuje się największym zagrożeniem dla płynności prowadzenia ruchu lotniczego. Odpowiada za to położenie lotniska w obrębie wklęsłej formy terenu, tj. Obniżenia Cholerzyńskiego, cechującego się tendencją do tworzenia zastoisk chłodnego powietrza oraz przyziemnych inwersji temperatury. 
Poprzez szczegółową analizę częstości i prawdopodobieństwa pojawiania się mgły wykazano jej istotny związek z cyrkulacją. Związek ten jest na tyle ścisły, że na podstawie prognozowanej sytuacji synoptycznej z dużym prawdopodobieństwem można przewidzieć wystąpienie mgły. Możliwość prognozowania wystąpienia mgły, jej gęstości oraz czasu zalegania jest niezwykle ważnym zagadnieniem w kontekście bezpieczeństwa załóg i pasażerów oraz wykonywanych zadań lotniczych.

\section{Literatura}

Bac S., Rojek M., 1979, Meteorologia i klimatologia, Państwowe Wydawnictwo Naukowe, Warszawa.

Bajkiewicz-Grabowska E., Kossowska-Cezak, E., 2008, Podstawy hydrometeorologii, Państwowe Wydawnictwo Naukowe, Warszawa.

Błaś M., Sobik M., 2004, The distribution of fog frequency in the Carpathians, Geographia Polonica, 77, 19-34.

Cabała S., 1990, Zró̋̇nicowanie i rozmieszczenie zbiorowisk leśnych na Wyżynie Ślaskiej, Prace Naukowe Uniwersytetu Śląskiego, 1068, Katowice.

Chromow S. P., 1977, Meteorologia i klimatologia, Państwowe Wydawnictwo Naukowe, Warszawa.

Domicz J., Szutowski L., 1998, Podręcznik pilota samolotowego, Technika, Poznań.

Głowacka A., Bąkowski R., Wiążewski W., Paradowski M., 2005, Weather patterns: conditions preceding fog formation at Warsaw and Cracow airports [w:] S.C. Michaelides (red.), Proceedings, Short range forecasting methods of fog, visibility and low clouds, Larnaca, Cyprus, 3-78.

Holec M., Tymański P., 1973, Podstawy meteorologii i nawigacji meteorologicænej, Wydawnictwo Morskie, Gdańsk.

Jafernik H., Wilczek Z., Ziarko J., 2000, Meteorologicæna ostona dziatań lotnictwa, Wydawnictwo Bellona, Warszawa.

Kondracki J., 2000, Geografia regionalna Polski, Państwowe Wydawnictwo Naukowe, Warszawa. Koronacki J., Mielniczuk J., 2011, Statystyka dla studentów kierunków technicznych i przyrodniczych, Wydawnictwo Naukowo-Techniczne, Warszawa.

Kożuchowski K. (red.), 2012, Meteorologia i klimatologia, Państwowe Wydawnictwo Naukowe, Warszawa.

Łupikasza E., Niedźwiedź T., 2016, Synoptic climatology of fog in selected locations of southern Poland (1966-2015), Bulletin of Geography, Physical Geography Series, 11, 5-15.

Matuszko D., Piotrowicz K., Kowanetz L., 2015, Klimat [w:] M Baścik., B. Degórska, (red.) Środowisko præyrodnicze Krakowa. Zasoby-Ochrona-Ksstałtowanie, IGiGP UJ, Kraków, 81-104. Morawska M., 1966, Mgty w Krakowie (1861-1960), Przegląd Geofizyczny, 11, 171-181.

Niedźwiedź T. (red.), 2003, Stownik meteorologiczny, Polskie Towarzystwo Geofizyczne, Instytut Meteorologii i Gospodarki Wodnej, Warszawa. 
Niedźwiedź T., 2013, Kalendar: typów cyrkulacji atmosfery dla Polski potudniowej - zbiór komputerowy, Uniwersytet Śląski, Katedra Klimatologii, Sosnowiec.

Nowak A., 1968, Mezoklimat Rowu Kræeszowickiego, Zeszyty Naukowe Uniwersytetu Jagiellońskiego, Prace Geograficzne, 18, 18-31.

Piwkowski H., 1976, Rozkład mgiet w Polsce i ich dtugotrwatośc, Przegląd Geofizyczny, 21, 41-49.

Pruchnicki J., 1987, Metody opracowań klimatologicænych, Państwowe Wydawnictwo Naukowe, Warszawa.

Reanalyses archives, http://www.wetterzentrale.de/topkarten/tkfaxbraar.htm (dostęp: 25.06.2019).

Skomorowski A., Piotrowski P., 2018, The occurrence of fog at meteorological stations located on the airport in Poland in the years 2005-2015, Przegląd Geofizyczny, 4, 315-327.

Wiążewski W., Bąkowski R., 2007, Sytuacje synoptyczne sprzyjajqce wystapieniu mgiet na lotnisku Kraków-Balice [w:] K. Piotrowicz, R. Twardosz (red.), Wahania klimatu w różnych skalach przestrzennych i czasowych, Instytut Geografii i Gospodarki Przestrzennej, Uniwersytet Jagielloński, Kraków, 337-345.

Woś A., 2010, Klimat Polski w drugiej potowie XX wieku, Poznań.

\author{
Magdalena Skrzyńska \\ Uniwersytet Jagiellonski w Krakowie \\ Instytut Geografii i Gospodarki Przestrzennej \\ ul. Gronostajowa 7, 30-387 Kraków \\ magda.michalik@doctoral.uj.edu.pl
}

